\title{
Wastewater-based epidemiology: a new frontier for tracking environmental persistence and community transmission of COVID-19
}

\author{
Harsh Dutta ${ }^{1} \cdot$ Geetanjali Kaushik ${ }^{2} \cdot$ Venkatesh Dutta ${ }^{3}$ (1) \\ Received: 23 July 2021 / Accepted: 4 November 2021 / Published online: 11 November 2021 \\ (c) The Author(s), under exclusive licence to Springer-Verlag GmbH Germany, part of Springer Nature 2021
}

\begin{abstract}
Recent research in many parts of the world has pointed towards evidence of SARS-CoV-2 RNA in both treated and raw municipal wastewater discharged by communities. Therefore, concerns regarding it being a possible enteric virus are abundant. Past history of SARS-CoV-1 outbreaks and viral survival information helps in establishing information regarding possible viral infectivity and survival of SARS-CoV-2. The paper examines the existing strategies and techniques including the efficacy of laboratory-based RT-qPCR technique for tracking environmental persistence and community transmission of COVID-19. Analysis of studies targeting untreated and treated wastewater as source of samples is carried out. The analysis shows that untreated samples were mostly positive for SARS-CoV-2 RNA in the target studies. Infectivity estimation from viral load data was found to be about two orders of magnitude higher than actual case data in one of the studies. Additionally, relevant research on environmental survivability of SARS-CoV-2 and possible gaps are examined. Biosensors and excretion metabolite tracking in viral detection are also examined, which hold tremendous importance for future research. Wastewater-based epidemiology (WBE) shows incredible promise in the near future for tracking environmental persistence and community transmission of highly infectious diseases such as SARS-CoV-2. With limited research available on SARSCoV-2 with regard to WBE, it is imperative that focus be established on the evidence-based targeted studies.
\end{abstract}

Keywords Bioaerosols $\cdot$ Biosensors $\cdot$ Enteric virus $\cdot$ Epidemiology $\cdot$ Municipal wastewater $\cdot$ SARS-CoV-2 $\cdot$ Sewage $\cdot$ RT-qPCR

\section{Introduction}

Severe acute respiratory syndrome-coronavirus-2 (SARS$\mathrm{CoV}-2$ ) has been an emergent virus, responsible for one of the deadliest global pandemics responsible for the death of more than four million people in less than 2 years starting 2020 (Amaro et al. 2021; Dyer 2021). The research work that

Communicated by Lotfi Aleya.

Responsible Editor: Lotfi Aleya

Venkatesh Dutta

dvenks@gmail.com

1 Department of Biochemical Engineering and Biotechnology, Indian Institute of Technology Delhi, Delhi, India

2 Department of Civil Engineering, Hi-Tech Institute of Technology, Aurangabad, Maharashtra, India

3 Department of Environmental Science, Babasaheb Bhimrao Ambedkar University, Lucknow, India has been done to control and understand the pandemic has been consistently comprehensive in the past 2 years. However, there are still rapidly developing methods to understand and monitor the disease for better surveillance and control (WHO 2020). While it has been established that the primary route of transmission is through aerosol particulate matter in terms of airborne droplets released by infected individuals (Leung et al. 2020), SARS-CoV-2 has been detected in human excreta. There are studies that establish viral load shedding through the faecal route (Jafferali et al. 2021; Xiao et al. 2020a). Consequently, wastewater-based epidemiology, or WBE, has become a potential source of scientific inquiry and research. There have been a number of studies that have established the effectiveness of using this method to monitor community prevalence in countries across the world, several of which have been reviewed in this paper. Although in the context of SARS-CoV-2, WBE is an emergent field, and therefore there is a dire need of research to establish its quality as a tool to monitor community transmission. This also means that improved risk assessment techniques on the 
potential of transmission of SARS-CoV-2 through faecaloral routes are needed.

The aim of this study is to critically evaluate major laboratory research that examines potential presence of SARS$\mathrm{CoV}-2$. Various strategies and techniques including the efficacy of laboratory-based RT-qPCR techniques are examined for tracking environmental persistence and community transmission of COVID-19. Additionally, relevant research on environmental survivability of SARS-CoV-2 and any gaps in it are examined. Wastewater-based epidemiology (WBE) shows considerable promise in the near future for tracking environmental persistence and community transmission of SARS-CoV-2.

\section{Overview of coronaviruses and SARS epidemiological history}

The term 'coronaviruses' in general refers to several viral genera of the subfamily Coronavirinae under the family Coronaviridae, of the order Nidovirales (Cui et al. 2019). In particular, these genera are Alphacoronaviruses, Betacoronaviruses, Gammacoronaviruses, and Deltacoronaviruses. It has been established that the alpha and beta genera primarily infect mammals and especially cause respiratory tract infections in humans (Cui et al. 2019). Three of these viruses, SARS-CoV-1, Middle East respiratory syndrome-coronavirus (MERS-CoV), and SARS-CoV-2, have been notable in causing severe lower respiratory tract infections in the past decades, amongst the total seven human coronaviruses that have been identified so far (Ge et al. 2020).

The earliest analyses of viral samples obtained from patients exhibiting viral pneumonia in Wuhan, China, in 2019 revealed that SARS-CoV-2, then dubbed novel coronavirus-2019 (nCoV-2019), was phylogenetically related to existing samples (Lu et al. 2020). Notably, two bat coronaviruses bat-SL-CoVZC45 and bat-SL-CoVZXC21 were found to have $88 \%$ sequence identity match with the samples obtained. Phylogenetic trees revealed it to be of the genus Betacoronavirus, with several distinctions from its 2003 counterpart. The initial outbreak amongst individuals in Wuhan was characterized by close contact and proximity to the Huanan seafood market, and it is currently theorized that the transmission occurred from Wuhan wildlife to humans (Ge et al. 2020). While existing work on bat coronaviruses implicate them as natural hosts of SARS-CoV-2, theories regarding secondary transmission chains through intermediate reservoirs have not been eliminated.

There are lessons that have been learned from history that have been implemented through the beginning until date in this pandemic, particularly in China which suffered the worst of the 2003 outbreak. A total of 5327 probable cases in mainland China, and 1755 in Hong Kong, out of a total 8096 cases worldwide were estimated (WHO 2015). This has resulted in a shift in public outlook and policy outlook on the pandemic in China, which is self-evident from the handling of publicly available information in both the pandemics. In case of SARS-CoV-1, the public was not made aware of the case counts. The existence of the disease was not acknowledged up to 6 months after the first case was registered in Guangdong (Liu et al. 2021). Compared to December 2019, where within 45 days of the first official case in Wuhan, viral sample collection and thorough epidemiological analyses were underway. However, Liu et al. do admit that policies that led to interventions in 2019 and 2020 were insufficient, in terms of early warning detection. Breaks in the communication channels led to failure of proper information being relayed timely to the Chinese CDC. This is specified as one amongst a few reasons for needing improvements in surveillance of infectious diseases (Liu et al. 2021).

\section{Wastewater-based epidemiology (WBE): methods and comparative analyses of targeted studies}

Wastewater-based epidemiology has gained traction since research work in the 1970s presenting ideas for analysing wastewater for illicit drug usage (Hignite and Azarnoff 1977). It has particularly garnered attention since 2001 due to using wastewater as a tool for tracking drug usage in communities (Daughton 2001). Therefore, its application in a pandemic such as coronavirus disease 2019 (COVID19), where the testing and tracking methods have remained analogous to the above-mentioned tracking techniques, does make sense. It is thus of no surprise that independent studies have been undertaken to better understand the nature of transmission and if wastewater is potentially a useful way to monitor the large-scale spread of SARS-CoV-2.

The existence and persistence of threatening viruses in water media, such as drinking water, freshwater, seawater, and municipal waste, is a well-documented phenomenon (La Rosa et al. 2012). Amongst many of these are viruses belonging to Picornaviridae, Adenoviridae, Hepeviridae, and Coronaviridae. The evidence, therefore, of infectivity of SARS-CoV-2 in gastrointestinal pathways is meaningful and sensible (Xiao et al. 2020a). The mechanism of receptor-mediated cellular entry and subsequent infection in the cells of the lower intestinal tract follows from the known viral infection pathways of SARS-CoV-2. The virus uses angiotensin-converting enzyme 2 (ACE2) receptors for infection, exhibited strongly by epithelial cells in the lower respiratory tract (Xiao et al. 2020a). The evidence thus presented confirms the presence of SARS-CoV-2 in abundance in gastric, rectal, and duodenal epithelial cells (Xiao et al. 2020b). Viral shedding through faecal routes 
and possibilities of infective capability remains to be elucidated, although viral RNA in faecal samples has been detected (Fig. 1). Indeed, when it came to establishing the presence of infectious SARS in samples, viral entities could be isolated in several samples. It could also be inferred that a mechanism of infection consisting of aerosol formation by faeces of infected individuals in wastewater was probable (Xiao et al. 2020a). Such a mechanism was hypothesized to be the case in an outbreak during the 2003 SARS pandemic in a Hong Kong-based private housing estate, where faulty sewage structure was found that could have contributed to the infection. Thus, both these studies inspire an outlook into other studies focused on community health through wastewater surveillance of viral RNA.

\section{Australia}

In a proof-of-concept study, Ahmed et al. (2020) present the viability of testing for viral RNA in untreated wastewater as a means of early detection of presence of SARS-CoV-2 in the community. The samples used for the study came from wastewater treatment plants in urban catchments in Southeast Queensland. The initial steps included sample concentration using two methods previously reported in literature, namely ultrafiltration and electronegative membrane extraction. The authors indicate that this choice of two methods was employed due the lack of available research into recovery rates of enveloped viral particles from wastewater samples. The samples were then subjected to reverse transcription quantitative PCR (RT-qPCR) to quantify and amplify any viral RNA present using two assay techniques, namely N_Sarbeco and NIID_2019_nCOV_N, both targeting the N protein forming RNA. As a means of quality control, a reference
RT-qPCR assay of Oncorhynchus keta sample with a known initial copy number was done to determine whether RT-qPCR inhibition was occurring. As a final means for confirming presence, the RT-qPCR products were sequenced using Sanger and MiSeq Illumina sequencing. The sequence reads were scrutinized heavily, with smaller, imperfect, or primer-less reads wholly discarded.

Amongst the collected samples, 22\% (2 out of 9) were positive for the presence of SARS-CoV-2 RNA, which were collected on March 27, 2020, and April 01, 2020. The RT-qPCR assays however were observed to produce conflicting results. N_Sarbeco confirmed positivity in these two samples; however, NIID_2019_nCOV_N did not. The two concentration methods employed also did not produce confident results, with ultrafiltration being successful in one sample and electronegative filter extraction in the other. The two samples that did give positive results were further verified to be correct after sequencing results and matching with existing reference genome MT276598.1. Further model-based estimation results gave a median number of infections from 171 to 1090 in the catchment population of 600,000 individuals.

A strong divergence from the work of Xiao et al. (2020a) comes in terms of the presence of infectious viral particles. Here, the authors described an insufficiency of evidence when it came to viral infections through wastewater. The authors however did recommend a strict adherence to standard PPE procedures while collecting samples. This recommendation extends to other research on municipal waste management as well. High-risk employees have been identified (Yousefi et al. 2021), including municipal workers in constant contact with municipal waste. In all, WBE was recommended for detection of early warning signs of spread in communities rather than a strict measure of the number of cases.
Fig. 1 Basic scheme for viral sample collection and analysis using RT-qPCR

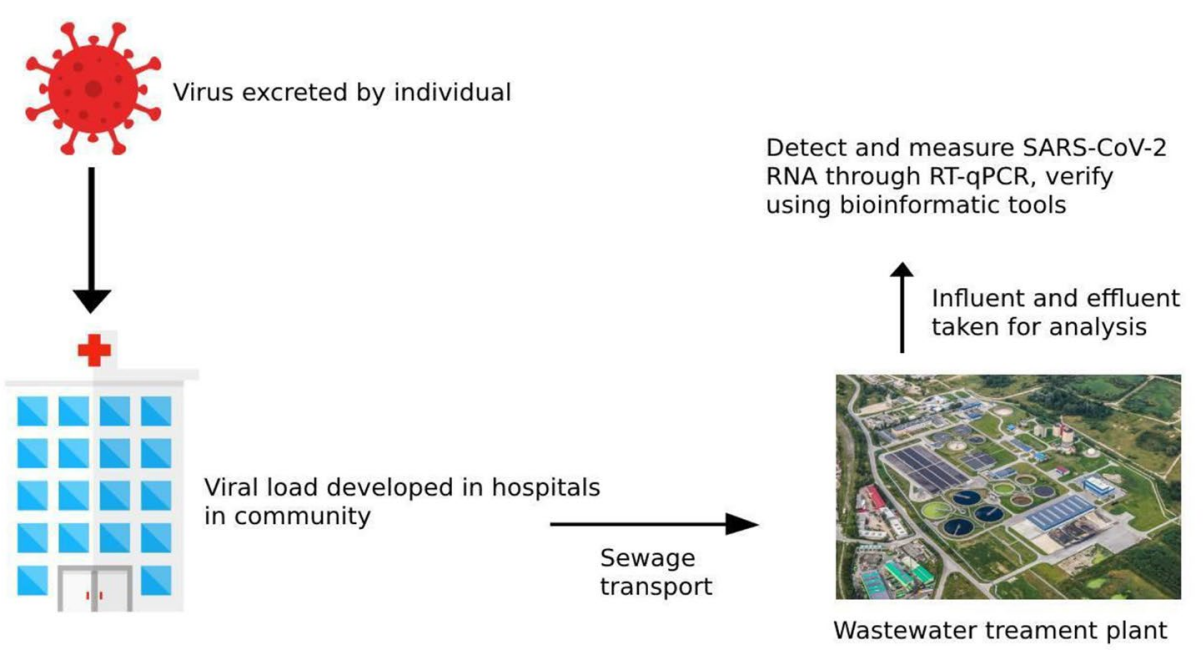




\section{USA}

The study conducted during 18 to 25 March 2020 in MA, USA (Wu et al. 2020) represented one of the earliest efforts in the USA to utilize WBE effectively and present both qualitative and quantitative evidence. Untreated sewage samples from two major treatment plants were obtained in the time frame, and a total of five sampling points were analysed. The first samples from 18 March 2020 were subjected to SARSCoV-2 S gene targeted PCR, and Sanger's sequencing of the PCR products resulted in a 97-98\% match from BLASTN suite, which was a confident match. With this result, sample concentration and RT-qPCR were the next logical steps.

The samples were concentrated using two methods, first using PEG 8000-based precipitation and the second using $0.2-\mu \mathrm{m}$ filters. PEG 8000 , while also precipitating bacterial nucleic acids alongside viral ones, was rather efficient and gave better and more consistent results than microfiltration. A total of six different samples for each $\mathrm{N}$ gene was thus analysed on the initial sampling date, the filtrate and filter content after $0.2-\mu \mathrm{m}$ treatment, and unfiltered sample. RT-qPCR was performed by targeting the $\mathrm{N}$ genes of SARS-CoV-2, and resultant viral titres could be obtained. To quantify the efficacy of this titre information, mainly due to uncertain variations in sewage, a reference qPCR on pepper mild mottle virus (PMMoV) was done. This was due to the fact that PMMoV is shed in large quantities from humans, and seasonal variations in wastewater titres are almost none to be observed. Therefore, by adjusting for any variation of PMMoV, a more accurate picture of viral load in sewage could be obtained. By normalizing these values for the median PMMoV titre value, a better trend was observed. It was noted that this corrected trend reflected the actual case growth in the city. However, this analysis was discussed to require more data in a longer time frame in order to be implemented or replicated.

It was observed that viral titre estimates coupled with data on viral shedding per person gave infectivity rates of $5 \%$ in the population, compared to the actual $0.026 \%$. This was chalked up to a number of major factors, one being that the research results were very conservative estimates. The data on viral load shedding was also a major factor, since it had a huge range that could significantly alter final infectivity rates. The final recommendations put forth were of studies analysing more catchments, so that better and corrected analytical methods could be developed. The study also noted that the qualitative trends could very well be used to inform and alter lockdown efforts and social distancing.

\section{India}

The first successful attempt at viral RNA detection in wastewater was done in Ahmedabad, Gujarat, during the lockdown period after the first confirmed case of COVID-19 in India on January 30, 2020 (Kumar et al. 2020). The target for sampling was the Old Pirana Wastewater Treatment Plant in Ahmedabad, Gujarat, which the researchers had chosen due to the fact that the plant was collecting sewage from government facilities treating COVID-19 patients. It was noted that due to the nature and timeline of the study, the focus was on observing variations with time in the samples. To that effect, treated and untreated wastewater samples were collected on two dates: May 8, 2020, and May 21, 2020. Sample concentration methods were also PEG based here, with the concentrated samples further subjected to viral RNA isolation using commercially available kits. MS2 phage particles were introduced to monitor extraction efficiency and to further be used to monitor RT-qPCR inhibition. RT-qPCR assays targeting the ORF1ab, N, and $\mathrm{S}$ genes were undertaken. The results were positive for the untreated samples, and all three of these genes could be detected in the samples from both dates. An attempt at quantifying the results of the RT-qPCR assay was done, and the results were consistent with the increasing number of cases from May 8, 2020, to May 27, 2020. The authors also noted that while this consistency is useful in determining the viability of monitoring tools, certain standards are required to be implemented in order to do comparative analyses of related studies across the world.

\section{Brazil}

The purpose of the study undertaken by Fongaro et al. (2021) in Santa Catarina, Brazil, was to establish whether SARS-CoV-2 had been circulating in the environment before the first clinical report of a confirmed SARS-CoV-2 patient in Brazil had been published. This first report was dated March 13, 2020. To that extent, raw, untreated sewage samples were independently obtained in a time period between October 30, 2019, and March 4, 2020. The samples were obtained from a single sewage system across six sampling points in the period, in central Florianopolis, Santa Catarina.

The samples were concentrated using a polyethylene glycol (PEG)-based method that had previously been reported to show satisfactory recovery rates (Wu et al. 2020). Murine norovirus particles were artificially added to the concentrated samples to establish a control for estimation of RNA extraction efficiency. RT-qPCR-based detection method was employed, using oligonucleotides and probes targeting N1, $\mathrm{S}$, and two RdRp regions in the viral genome. The amplicons obtained in RdRp- and S-based RT-qPCR were sequenced using Illumina sequencing and were found to have a $100 \%$ identity match with available SARS-CoV-2 sequence data. Deep Illumina sequencing of samples from November, 27, 2019, was done, and obtained reads were mapped against the genome data available in the entire Coronaviridae 
family. The reads were found to associate only with the SARS-CoV-2 genome. BLAST analysis also confirmed the sequences to be of SARS-CoV-2 origin, with a similarity result of $99.38 \%$ with it from the available data in BLAST. The most interesting result obtained was that SARS-CoV-2 RNA was detected in samples going as far back as November 27, 2019, weeks before the first case was reported in the Americas, and months before in Brazil. This implied the presence of heavy viral load in humans of the region a significant time before any official case of the disease was reported. This however could not be confirmed due to a lack of clinical data before January 2020, since clinical investigations in Brazil began in January regarding COVID-19.

A comparative analysis of several other key studies including the aforementioned three is depicted in Table 1. Comparisons on the basis of sample type, sample concentration method, target gene, and net sample positivity are done. It is important to note that the potential source of positive information is untreated wastewater in these studies. Treated wastewater samples were found to be either devoid of RNA entirely (Kumar et al. 2020) or producing positive results that pose questions related to what treatment strategies could be adopted to remove viral presence entirely.

While analysing treated wastewater, it is expected that some treatment methods would be effective enough to remove RNA or viral particles completely and may tend to give false negatives, if used as testing samples. A study undertaken in Iranian cities of Tehran, Qom, and Anzali (Nasseri et al. 2021) that looked at SARS-CoV-2 presence in three treatment plants found that RNA was absent in samples taken from treated wastewater in Qom and East Anzali. However, two chlorine disinfected wastewater samples out of four taken from Tehran showed positive results. This was chalked up to deficiencies in the standards of operation and management of the facility (Nasseri et al. 2021). The RNA retention in treated wastewater is further corroborated from the work of Tanhaei et al. (2021), where the $20 \%$ negativity came from a single treatment plant which had previously given positive presence in untreated samples. It may therefore be postulated that the other three treatment facilities were not performing up to the mark and hence could be putting workers at risk. Nasseri et al. (2021) do indeed put forth recommendations for proper performance of treatment facilities and for workers to adhere to standard PPE protocols. UV disinfection methods prove to be more successful than chlorine-based disinfection, and activated sludge processes seem to disinfect wastewater of SARS-CoV-2 RNA more effectively (Nasseri et al. 2021). A similar result is observed in UASB and aeration pond treated wastewater in Ahmedabad (Kumar et al. 2020), where RNA was absent entirely in the samples.

A major aspect that is put forth is that the qualitative analysis of this emerging information might be of more relevance. As discussed earlier, Ahmed et al. (2020) presented the idea of utilizing viral RNA loads as early information on potential outbreaks. In agreement with this, research on the infection dynamics of SARS-CoV-2 in Paris, France, suggests a significant relationship between viral RNA load in wastewater and human epidemiological data (Wurtzer et al. 2020). It is even hypothesized that undertesting might have occurred, and essential information about onset of infections may be obtained from wastewater data. This however was said to have a limited scope in mostly local regions. The policy-making aspects of WBE, however, are very impactful. By having access to quantitative information that may accurately describe epidemiological conditions, agencies making dynamic changes in social policies can be smoother and adaptable (Al Huraimel et al. 2020).

\section{SARS-CoV-2 as a potential enteric virus: environmental persistence and further scope of infection through wastewater}

Several mammalian and avian, including human, coronaviruses are linked to causing gastroenteritis in the species they infect (Cimolai 2020). Therefore, it comes as no surprise that these viruses are in fact classified as enteric viruses amongst several other members of the Caliciviridae, Astroviridae, Reoviridae, Adenoviridae, and Parvoviridae families (Sbaoui et al. 2021). These viruses have the ability to reach intestinal mucosal linings and infect enterocytes and primarily spread via a faecal-oral route (Saif 1999). While questions regarding the presence of SARS-CoV-2 in the gastrointestinal tract have been raised, for instance, whether it is due to indirect causes such as swallowing of sputum in infected individuals (Cimolai 2020), the work of Xiao et al. (Xiao et al. 2020b) strongly suggests otherwise. This coupled with studies that indicate presence of viral RNA in almost $48 \%$ of stool samples collected from patients, even after tests of respiratory tract infection came back negative (Cheung et al. 2020) points towards further research needs. In particular, an outlook into whether SARS-CoV-2 has the infective capabilities of its other enteric brethren, and whether current research needs are being met regarding this, has to be addressed.

Enteric viruses are shed in high numbers through faeces of infected individuals (Fig. 2), and in developing countries where conventional sanitation techniques have been the norm, they pose a huge risk (Upfold et al. 2021). Ineffective treatment techniques coupled with poor quality control of existing infrastructure means that these viruses have more avenues to persist in the environment. It has been pointed out that SARS-CoV-2 could utilize these water bodies as potential environmental reservoirs, and considering the high rate of infectivity, it would be 
Table 1 Comparison of RT-qPCR analyses for monitoring viral RNA presence in wastewater in different parts of the world

\begin{tabular}{|c|c|c|c|c|c|c|}
\hline Country & Region/city & Wastewater type & $\begin{array}{l}\text { Sample concentra- } \\
\text { tion method }\end{array}$ & Positivity rate & $\begin{array}{l}\text { RT-qPCR target } \\
\text { gene }\end{array}$ & Reference \\
\hline \multirow[t]{2}{*}{ Australia } & \multirow[t]{2}{*}{ QLD } & \multirow[t]{2}{*}{$\begin{array}{l}\text { Untreated waste- } \\
\text { water }\end{array}$} & $\begin{array}{l}\text { Electronega- } \\
\text { tive membrane } \\
\text { extraction }\end{array}$ & $\begin{array}{l}\text { 1/9; only from } \\
\text { N_Sarbeco }\end{array}$ & \multirow[t]{2}{*}{$\mathrm{N}$ gene } & \multirow[t]{2}{*}{ Ahmed et al. (2020 } \\
\hline & & & Ultrafiltration & $\begin{array}{l}\text { 1/9; only from } \\
\text { N_Sarbeco }\end{array}$ & & \\
\hline \multirow[t]{2}{*}{ India } & \multirow[t]{2}{*}{ Ahmedabad } & $\begin{array}{l}\text { Untreated waste- } \\
\text { water }\end{array}$ & \multirow[t]{2}{*}{$\begin{array}{l}\text { PEG 9000-based } \\
\text { precipitation }\end{array}$} & $\begin{array}{c}\text { May 8, 2020, May } \\
\text { 27, 2020: } 100 \%\end{array}$ & \multirow[t]{2}{*}{$\begin{array}{l}\text { ORF1ab, N, and } \mathrm{S} \\
\text { genes }\end{array}$} & \multirow[t]{2}{*}{ Kumar et al. (2020) } \\
\hline & & $\begin{array}{l}\text { UASB and aeration } \\
\text { pond treated } \\
\text { wastewater }\end{array}$ & & $\begin{array}{c}\text { May } 8,2020, \text { May } \\
27,2020: 0 \%\end{array}$ & & \\
\hline The Netherlands & $\begin{array}{l}\text { Amsterdam, Den } \\
\text { Haag, Utrecht, } \\
\text { Apeldoorn, } \\
\text { Amersfoort, Til- } \\
\text { burg, Schiphol }\end{array}$ & $\begin{array}{l}\text { Untreated waste- } \\
\text { water }\end{array}$ & Ultrafiltration & $\begin{array}{l}\text { 4/13 }(\text { sam- } \\
\text { ples } 3 \text { weeks } \\
\text { before }+1 \text { week } \\
\text { after first } \\
\text { reported } \\
\text { case). N1: } 3 / 13 \text {, } \\
\text { N2: } 2 / 13, \mathrm{~N} 3: \\
\text { 3/13, E: } 2 / 13\end{array}$ & $\mathrm{~N}$ and $\mathrm{E}$ genes & $\begin{array}{l}\text { Medema et al. } \\
\text { (2020) }\end{array}$ \\
\hline China & Hangzhou & $\begin{array}{l}\text { Hospital sewage } \\
\text { discharge }\end{array}$ & NA & $\begin{array}{l}\text { Untreated and } \\
\text { preprocessed: } \\
\text { 100\% (4/4), Final } \\
\text { outlet: } 0 \%\end{array}$ & NA & Wang et al. (2020) \\
\hline USA & MA & $\begin{array}{l}\text { Untreated waste- } \\
\text { water }\end{array}$ & $\begin{array}{l}\text { PEG } 8000-\text { based } \\
\text { precipitation }\end{array}$ & $\begin{array}{l}\text { Concentration } \\
\text { analysis: } 66.67 \% \\
\text { (N gene); Sample } \\
\text { positivity in time } \\
\text { frame: } 100 \%\end{array}$ & $\mathrm{~N}$ genes & Wu et al. (2020) \\
\hline Italy & Milan, Rome & $\begin{array}{l}\text { Untreated waste- } \\
\text { water }\end{array}$ & $\begin{array}{l}\text { PEG-Dextran- } \\
\text { based precipita- } \\
\text { tion }\end{array}$ & $50 \%(6 / 12)$ & $\begin{array}{l}\text { ORF1ab, S, and } \\
\text { RdRp genes }\end{array}$ & $\begin{array}{l}\text { La Rosa et al. } \\
\text { (2020) }\end{array}$ \\
\hline France & Paris & $\begin{array}{l}\text { Untreated waste- } \\
\text { water }\end{array}$ & $\begin{array}{l}\text { PowerFecal Pro Kit } \\
\text { (QIAGEN) based } \\
\text { extraction }\end{array}$ & $100 \%$ & $\mathrm{E}$ and RdRp genes & $\begin{array}{l}\text { Wurtzer et al. } \\
\text { (2020) }\end{array}$ \\
\hline Spain & Murcia & $\begin{array}{l}\text { Untreated and } \\
\text { treated waste- } \\
\text { water }\end{array}$ & $\begin{array}{l}\text { Aluminium } \\
\text { hydroxide } \\
\text { adsorption-pre- } \\
\text { cipitation }\end{array}$ & $\begin{array}{l}\text { Untreated: } 83 \% \\
\quad(35 / 42) \\
\text { Secondary treated: } \\
11 \%(2 / 18) \\
\text { Tertiary treated: } \\
0 \%\end{array}$ & $\mathrm{~N}$ genes & $\begin{array}{l}\text { Randazzo et al. } \\
\text { (2020) }\end{array}$ \\
\hline Brazil & Santa Catarina & $\begin{array}{l}\text { Untreated waste- } \\
\text { water }\end{array}$ & $\begin{array}{l}\text { PEG } 6000-\text { based } \\
\text { precipitation }\end{array}$ & $\begin{array}{l}\text { Oct 30, 2019, Nov } \\
\text { 6, 2019: 0\% } \\
\text { Nov 27, 2019, Dec } \\
\text { 11, 2019, Feb } \\
\text { 20, 2020, Mar 4, } \\
\text { 2020: } 100 \%\end{array}$ & $\begin{array}{l}\text { N1, S, and two } \\
\text { RdRp genes }\end{array}$ & $\begin{array}{l}\text { Fongaro et al. } \\
\text { (2021) }\end{array}$ \\
\hline Serbia & Danube River & $\begin{array}{l}\text { Untreated waste- } \\
\text { water }\end{array}$ & Ultrafiltration & $\begin{array}{l}\text { 4/8; N1: 2/8, N2: } \\
\quad \text { 4/8, E: } 2 / 8\end{array}$ & $\mathrm{~N}$ and $\mathrm{E}$ genes & $\begin{array}{l}\text { Kolarević et al. } \\
\text { (2021) }\end{array}$ \\
\hline Iran & Tehran & Treated wastewater & $\begin{array}{l}\text { Electronegative } \\
\text { filter followed by } \\
\text { PEG } 6000-\text { based } \\
\text { precipitation }\end{array}$ & $8 / 10$ & $\begin{array}{l}\text { ORF1b and } \mathrm{N} \\
\text { genes }\end{array}$ & $\begin{array}{l}\text { Tanhaei et al. } \\
\text { (2021) }\end{array}$ \\
\hline
\end{tabular}


Fig. 2 Bioaerosol formation from waste and droplets generated by infected individuals

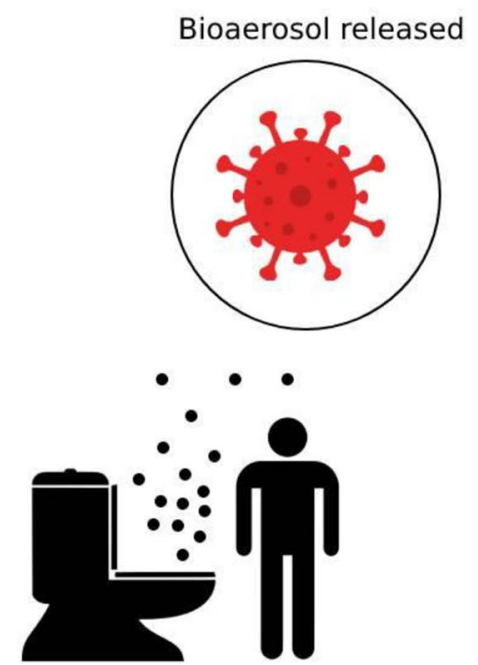

Infected person using toilets

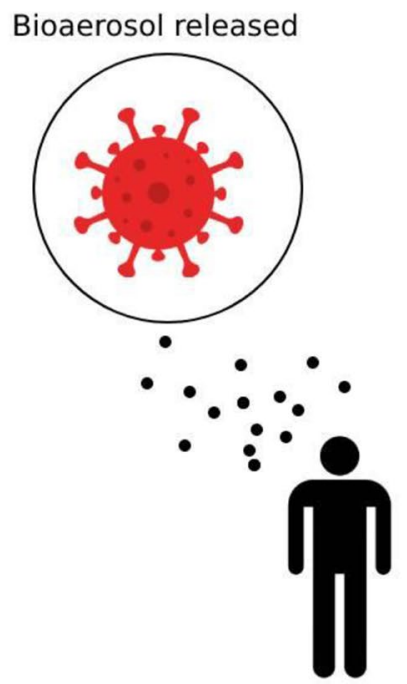

Infected person sneezing, coughing a serious issue to deal with in these countries (Danchin et al. 2020). An important counterpoint to note is that despite the putative assumptions and circumstantial evidence, there has not been any concrete evidence for the presence of active SARS-CoV-2 virions in wastewater, but only of fragmented particles, in particular RNA (Ahmed et al. 2020; Wu et al. 2020; Kumar et al. 2020; Fongaro et al. 2021; Medema et al., 2021; Kolarević et al. 2021; Tanhaei et al. 2021). It has been established concretely that the primary mode of transmission of the virus is via aerosols and microscopic droplets (Leung et al. 2020), and this corroborates the local 2003 SARS-CoV-1 outbreak in a Hong Kong housing estate previously discussed (Xiao et al. 2020a). Hence, an indirect infective route using wastewater as a carrier might also be postulated.

The wastewater-bioaerosol infectivity pathway has to be evaluated clearly, considering recent research on pathogen viability. Model estimations of how inhaled doses of contaminated air can infect individuals have to be done, so that any potential risks can be isolated. Quantitative microbial risk assessment (QMRA) is an established technique that has been utilized in the context of SARS-CoV-2 (Zaneti et al. 2021; Gholipour et al. 2021). The first work of its kind was done in Porto Alegre, South Brazil (Zaneti et al. 2021), and it was highlighted via QMRA results that infection risks were in fact quite above tolerable levels. The work of Gholipour et al. (2021) estimated this risk by utilizing similar techniques. The focus was wastewater plant workers who were expected to be greatly exposed to contaminated bioaerosol. By estimating daily dose inhalation through a model based on past research on noroviruses, the study was able to identify probabilities of infection. While assuming that no pathogen decay occurred in the entire transportation and handling of raw wastewater, it was estimated that the annual infection risk for workers was 1 log higher than recommended WHO guidelines (Gholipour et al. 2021).

When it comes to discussing poor quality control in treatment plants, the reasons for persistence of RNA may vary from lack of proper treatment steps to septic sewage leaks into natural water bodies. Even treated wastewater may transport RNA into environments that do not contain any virions (Wurtzer et al. 2020). This presence in natural water bodies has been observed in river samples in Italy (Rimoldi et al. 2020).

With no studies present that gauge actual virions in water samples, we can look towards previous reports on SARSCoV-1 and MERS-CoV to deduce a baseline for SARSCoV-2 survivability and infectivity in water environments. Consequently, we can compare them to currently reported behaviour of SARS-CoV-2. A 2005 study in Beijing, China, on the persistence of SARS-CoV-1 under different physical stresses, aimed to deduce the reasons for the persistence of the virus and to analyse the effect of disinfecting substances on the viral load (Wang et al. 2005). Samples were collected from the 309th hospital in Beijing, where patients with SARS were being treated. Testing samples included hospital sewage supernatant, domestic sewage, dechlorinated tap water, and a PBS standard. RNA-based detection determined that the virus lasted 2 days in the sewage media and the tap water medium but remained in PBS for 14 days until the end of the experiment, all kept at 20 degrees Celsius. At 4 degrees however, the virus remained active for all 14 days in all the media. Compared to a more recent work on SARS-CoV-2, the viral survivability was up to 5 days at ambient temperatures with similarly high preservation seen at 4 degrees Celsius (Chan et al. 2020). With respect to disinfectant capability, chlorine and chlorine dioxide were used to investigate SARS-CoV-1 in the Beijing study (Wang et al. 2005). It was found that for chlorine, at 
least $10 \mathrm{~min}$ of contact time and $10 \mathrm{mg} / \mathrm{L}$ concentration were required for the virus to be fully inactivated, and for chlorine dioxide, at least $40 \mathrm{mg} / \mathrm{L}$ concentration was required. As far as the contact time was concerned, chlorine dioxide inactivation efficiency peaked at about $68 \%$, with a decline starting at $30 \mathrm{~min}$ of contact. In the SARS-CoV-2 study, 75\% ethanol showed a 1.83 units $\log$ reduction after 1 min of contact time, and $10 \%$ commercial bleach which was a sodium hypochlorite solution showed 3.25 units log reduction after 1 min of contact (Chan et al. 2020). This in conjugation with the work of Gundy et al. on feline infectious peritonitis virus, and human coronavirus 229E, used as a representative for SARS-CoV-1 also confirmed rapid decline in survivability at ambient temperatures of coronaviruses (Gundy et al. 2009). This is assuring in the context of SARS-CoV-2 survivability in municipal sewage; however, the relatively longer survival periods of SARSCoV-2 (Chan et al. 2020) poses a potential threat in intermediate stages of disinfection and treatment. Solar stills that use thermal desalination techniques to treat some forms of wastewater are reported to be ineffective in removing SARS-CoV-2 virions due to droplet formation and therefore pose a potential transmission risk during the treatment process (Parsa 2021). Additional research of SARS-CoV-2 persistence in environmental surfaces (Gholipour et al. 2020) has also tackled the issue on viability of virus particles. While low concentrations have been observed in public surfaces which are not enough for infectivity, the work may translate to testing survival capacity of viruses in wastewater media. This time period of survival in normal environments might be relatively shorter, but considering the volume and the rate of generation of municipal and biomedical wastes, it poses a reasonable threat. Normal biomedical effluent discharge from hospitals is expected to have persistent viral particles (Khan et al. 2021). Considering the massive waste load municipal entities are expected to process, and the fact that SARS-CoV-2 may remain viable for up to $48 \mathrm{~h}$ in untreated sewage, infection risks for WWTP workers are very high.

There is a definitive lack of information and research concerning SARS-CoV-2 infectivity through water media (Sbaoui et al. 2021), and only one study so far based in Italy has had a definitive report on whether infections are possible. It reported a lack of cytopathic ability in all the samples cultured on host cells, which was linked to direct infectivity of the virus (Rimoldi et al. 2020). Therefore, it could be then followed that essential treatment processes were rendering the virus destroyed or ineffective.

\section{Improvements in technology and methods}

The conventional method for performing RT-qPCR is reliable and accurate when it comes to determining presence of target nucleic acid sequences. Improvements upon it are usually met by targeting inefficacies such as the inability for it to report sequences from active versus inactive virions or a need for testing that is not labour- or time-intensive. In addition, these improvements are coupled with those on RNA extraction methods from samples as well. It has been reported that an efficient amino-modified magnetic nanoparticle-based method has been employed in RNA extraction (Zhao et al. 2020) that reduces the time required during testing.

Biosensors are devices capable of generating information through physical means, for example, optical or electrical signals by using biological entities such as peptides or nucleic acids as input signals (Demeke et al. 2020). Since the main idea behind WBE is to provide community health tracking information, biosensors may be used to detect and provide a qualitative response in regions where resourceintensive RT-qPCR may not be affordable. Biosensors aim to provide near real-time information that is both practical and affordable (Yang et al. 2015). This may aid in timely responses by agencies such as CDC looking to prune community outbreaks. Paper-based analytical devices, or PADs, have been generating interest in their uses as biosensors capable of being point-of-care diagnostic tools, since they had already gained traction for analysis of bacteria and viruses in the past (Yetisen et al. 2013). Their uses in wastewater surveillance for tracking of SARS-CoV-2 has therefore gained interest, particularly due to a reported history of testing for HIV, Escherichia coli, and Zika virus, amongst others (Mao et al. 2020). While there has been an expected need for improvement with regard to the sensitivity and signal readout of PADs (Liu et al. 2019), modifications to PADs may overcome these challenges. Integration of colorimetric assays can increase their capacity to generate quantitative information, and usage of gold or silver nanoparticles with the sensor platforms greatly enhances optical signals (Demeke et al., 2020). Printed circuit board (PCB) biosensors may also be utilized to detect presence of various RNA amplicons in wastewater samples. It has been recently reported that PCB biosensors were able to detect SARSCoV-2 N1 RNA in control samples (Kumar et al. 2021).

The work of Daughton et al. and subsequent research in wastewater-based tracking of both legal and illegal drug usage in communities has had massive implications for surveillance of COVID-19 (Daughton 2001). In particular, the interest in metabolites that are formed as excretion products in individuals using these drugs has increased since and continues to be one of the most important techniques used to monitor community drug abuse (González-Mariño et al. 2020; Croft et al. 2020; Senta et al. 2014; Nowicki et al. 2014). The earliest work of this kind dates back to 2005 , where cocaine and benzoylecgonine, a urinary metabolite shed by cocaine users, were monitored in the river Po in Italy using mass spectrometry (Zuccato et al. 2005). The 
metabolites shed by SARS-CoV-2-infected individuals can therefore be used as alternative biomarkers to RNA/DNA for COVID-19 surveillance. Several metabolites shed through urine, faeces, and breath of infected individuals have been noted as potential biomarkers (Anand et al. 2021), although the biggest concerns and challenges regarding the selection include stability in wastewater and ease of extraction and concentration.

\section{Potential research risks and recommendations}

As proposed by other research into this field, the qualitative analysis of viral load data is a great indicator of potential community outbreaks. Further research into developing this aspect might be of great relevance to public authorities. Improvements on sample collection can be made, and greater focus on obtaining viable virions from wastewater samples can be done. This would allow for proper analysis of infection risks, as modelled by several research groups. An important point to note, however, is that qualitative data can only be utilized to better understand local spread and implementation of policies locally. A major lack of quantitative data regarding total infections in a catchment is holding back the field. Therefore, it has to be noted that without a reliable method to quantify infectivity from viral RNA load data, it would be difficult to get an accurate picture of the number of cases. Apart from this, WBE has been recommended by several groups as a tracking and surveillance tool, and not for estimating transmission risks. Developments into better understanding of viral load shedding, viral RNA retention in sewage, and virion survival in sewage can definitively improve the way future research can analyse sewage RNA load.

Current research work on isolating and growing SARS$\mathrm{CoV}-2$ under proper growth conditions might be a lucrative aspect that can be analysed in this field. By development of protocols that can efficiently isolate viable virions, without sample inactivation during handling, can improve research concerning wastewater-based transmission. Forays into nanotechnology and faster analysis techniques provide the concerning research with better tools and certainly make this emergent field relevant and interesting.

\section{Concluding remarks}

The COVID-19 pandemic has challenged the existing health monitoring infrastructure, particularly due to its high infectivity. Therefore, the need for improvement in rapid surveillance and tracking the environmental persistence is of utmost importance. Wastewater-based epidemiology is an established monitoring technique which has been used extensively in analysing community drug abuse. While there is a wealth of available literature on the topic, the present study aims to evaluate recent laboratory research comprehensively and critically. In addition, it also aims to provide a well-rounded body of information while being a relatively short review. Therefore, the presented body of work has attempted to be meaningful yet concise. There are some definite limitations of this work, particularly in discussing the future of WBE and research needs.

WBE has a strong potential in the near future as a tracking and surveillance tool, especially in events of highly infectious diseases such as SARS-CoV-2. This paper reviews and compares various studies that have reported virus concentration in municipal wastewater for subsequent RT-qPCR detection of viral RNA. Wastewater-based epidemiology is important in cases like COVID-19 where rapid information in real time is required. While limited research is available that substantially refutes SARS-CoV-2 as an enteric virus, the history of coronaviruses is sufficient for a requirement of more research. Viral load measurement and subsequent estimation of SARS-CoV-2 cases in municipal wastewater is limited and imprecise. RT-qPCR is capable of testing SARSCoV-2 RNA in both treated and untreated wastewater. Optimized methods for SARS-CoV-2 detection in wastewater are extremely needed. Biosensors and metabolite tracking improve real-time tracking aspects of WBE and are promising in terms of their accessibility.

While only RT-qPCR-based analysis has gained momentum, certain aspects need to be elucidated. Model-based estimations that can accurately reflect the number of infected individuals based off of viral load data, which sampling points give better results and whether there is an actual transmission risk through wastewater, are some of these aspects. Quantification of cases is still a big challenge, with Monte Carlo simulations being implemented that require more data to be precise. In the case of gauging transmission risk, a limited piece of work exists in the literature which is mostly site-specific lacking detailed assessment. Sample collection, extraction, and concentration are all aspects that are being studied and being enhanced. Technological improvements are catching up to demands of rapid and accessible testing, with qualitative results that can be the basis for effective agency responses. Inefficiencies with the quantification of environmental data at several steps make the qualitative aspects more attractive as a result. With improvements in mass testing and analysis being examined, and looking back at histories of past outbreaks, WBE is certainly coming up to the challenge of establishing community health resources and containing threats to it.

Acknowledgements HD duly acknowledges the support provided by the Department of Biochemical Engineering and Biotechnology, 
IIT-Delhi to carry out this study. The authors are thankful to the anonymous referees whose feedback helped to improve the paper.

Author contribution HD - literature survey, draft preparation; VD - literature survey, critical review, editing, proofreading; GK - conceptualization, review.

Availability of data and materials Not applicable.

\section{Declarations}

Ethics approval and consent to participate. Not applicable.

Consent for publication. Not applicable.

Competing interests The authors declare no competing interests.

\section{References}

Ahmed W, Angel N, Edson J, Bibby K, Bivins A, O’Brien JW, Choi PM, Kitajima M, Simpson SL, Li J, Tscharke B, Verhagen R, Smith W, Zaugg J, Dierens L, Hugenholtz P, Thomas KV, Mueller JF (2020) First confirmed detection of SARS-CoV-2 in untreated wastewater in Australia: a proof of concept for the wastewater surveillance of COVID-19 in the community. Sci Total Environ 728:138764. https://doi.org/10.1016/j.scitotenv. 2020.138764

Al Huraimel K, Alhosani M, Kunhabdulla S, Stietiya MH (2020) SARS-CoV-2 in the environment: modes of transmission, early detection and potential role of pollutions. Sci Total Environ 744:140946. https://doi.org/10.1016/j.scitotenv.2020.140946

Amaro JE, Dudouet J, Orce JN (2021) Global analysis of the COVID19 pandemic using simple epidemiological models. Appl Math Model 90:995-1008

Anand U, Adelodun B, Pivato A, Suresh S, Indari O, Jakhmola S, Jha HC, Jha PK, Tripathi V, Di Maria F (2021) A review of the presence of SARS-CoV-2 RNA in wastewater and airborne particulates and its use for virus spreading surveillance. Environ Res 196:110929. https://doi.org/10.1016/j.envres.2021.110929

Chan KH, Sridhar S, Zhang RR, Chu H, Fung AY, Chan G, Chan JF, To KK, Hung IF, Cheng VC, Yuen KY (2020) Factors affecting stability and infectivity of SARS-CoV-2. J Hosp Infect 106(2):226231. https://doi.org/10.1016/j.jhin.2020.07.009

Cheung KS, Hung I, Chan P, Lung KC, Tso E, Liu R, Ng YY, Chu MY, Chung T, Tam AR, Yip C, Leung KH, Fung AY, Zhang RR, Lin Y, Cheng HM, Zhang A, To K, Chan KH, Yuen KY, ... Leung WK (2020) Gastrointestinal manifestations of SARS-CoV-2 infection and virus load in fecal samples from a Hong Kong cohort: systematic review and meta-analysis. Gastroenterology, 159(1), 81-95. https://doi.org/10.1053/j.gastro.2020.03.065

Cimolai N (2020) Features of enteric disease from human coronaviruses: implications for COVID-19. J Med Virol 92(10):18341844. https://doi.org/10.1002/jmv.26066

Croft TL, Huffines RA, Pathak M, Subedi B (2020) Prevalence of illicit and prescribed neuropsychiatric drugs in three communities in Kentucky using wastewater-based epidemiology and Monte Carlo simulation for the estimation of associated uncertainties. J Hazard Mater 384:121306. https://doi.org/10.1016/j.jhazmat.2019.121306

Cui J, Li F, Shi ZL (2019) Origin and evolution of pathogenic coronaviruses. Nat Rev Microbiol 17(3):181-192. https://doi.org/10. 1038/s41579-018-0118-9
Danchin A, Ng TW, Turinici G (2020) A new transmission route for the propagation of the SARS-CoV-2 coronavirus. Biology 10(1):10. https://doi.org/10.3390/biology 10010010

Daughton CG (2001) Illicit drugs in municipal sewage. Pharmaceuticals and Care Products in the Environment 791:348-364. https://doi.org/10.1021/bk-2001-0791.ch020

Demeke AT, Samaddar M, Alharbi MG, Al-Hindi RR, Bhunia AK (2020) Biosensor and molecular-based methods for the detection of human coronaviruses: a review. Mol Cell Probes 54:101662. https://doi.org/10.1016/j.mcp.2020.101662

Dyer, O. (2021). Covid-19: Study claims real global deaths are twice official figures. BMJ: British Medical Journal (Online), 373.

Fongaro G, Stoco PH, Souza D, Grisard EC, Magri ME, Rogovski P, Schörner MA, Barazzetti FH, Christoff AP, de Oliveira L, Bazzo ML, Wagner G, Hernández M, Rodríguez-Lázaro D (2021) The presence of SARS-CoV-2 RNA in human sewage in Santa Catarina, Brazil, November 2019. Sci Total Environ 778:146198. https://doi.org/10.1016/j.scitotenv.2021.146198

Ge H, Wang X, Yuan X, Xiao G, Wang C, Deng T, Yuan Q, Xiao $X$ (2020) The epidemiology and clinical information about COVID-19. European Journal of Clinical Microbiology \& Infectious Diseases : Official Publication of the European Society of Clinical Microbiology 39(6):1011-1019. https://doi.org/10. 1007/s10096-020-03874-z

Gholipour S, Mohammadi F, Nikaeen M, Shamsizadeh Z, Khazeni A, Sahbaei Z, Mousavi SM, Ghobadian M, Mirhendi H (2021) COVID-19 infection risk from exposure to aerosols of wastewater treatment plants. Chemosphere 273:129701. https://doi. org/10.1016/j.chemosphere.2021.129701

Gholipour S, Nikaeen M, Mohammadi Manesh R, Aboutalebian S, Shamsizadeh Z, Nasri E, Mirhendi H (2020) Severe acute respiratory syndrome coronavirus 2 (SARS-CoV-2) contamination of high-touch surfaces in field settings. Biomed Environ Sci: BES 33(12):925-929. https://doi.org/10.3967/bes2020.126

González-Mariño, I., Baz-Lomba, J. A., Alygizakis, N. A., AndrésCosta, M. J., Bade, R., Bannwarth, A., ... \& Ort, C. (2020). Spatio-temporal assessment of illicit drug use at large scale: evidence from 7 years of international wastewater monitoring. Addiction, 115(1), 109-120. https://doi.org/10.1111/add. 14767

Gundy PM, Gerba CP, Pepper IL (2009) Survival of coronaviruses in water and wastewater. Food Environ Virol 1(1):10-14. https://doi. org/10.1007/s12560-008-9001-6

Hignite C, Azarnoff DL (1977) Drugs and drug metabolites as environmental contaminants: chlorophenoxyisobutyrate and salicylic acid in sewage water effluent. Life Sci 20(2):337-341. https://doi. org/10.1016/0024-3205(77)90329-0

Jafferali MH, Khatami K, Atasoy M, Birgersson M, Williams C, Cetecioglu Z (2021) Benchmarking virus concentration methods for quantification of SARS-CoV-2 in raw wastewater. Sci Total Environ 755:142939

Khan AH, Aziz HA, Khan NA, et al. (2021). Impact, disease outbreak and the eco-hazards associated with pharmaceutical residues: a critical review. Int J Environ Sci Technol. https://doi.org/10.1007/ s13762-021-03158-9

Kolarević S, Micsinai A, Szántó-Egész R, Lukács A, Kračun-Kolarević M, Lundy L, Kirschner A, Farnleitner AH, Djukic A, Čolić J, Nenin T, Sunjog K, Paunović M (2021) Detection of SARS-CoV-2 RNA in the Danube River in Serbia associated with the discharge of untreated wastewaters. Sci Total Environ 783:146967. https:// doi.org/10.1016/j.scitotenv.2021.146967

Kumar, M. S., Nandeshwar, R., Lad, S. B., Megha, K., Mangat, M., Butterworth, A., ... \& Tallur, S. (2021). Electrochemical sensing of SARS-CoV-2 amplicons with PCB electrodes. Sensors and Actuators B: Chemical, 130169. https://doi.org/10.1016/j.snb. 2021.130169 
Kumar M, Patel AK, Shah AV, Raval J, Rajpara N, Joshi M, Joshi CG (2020) First proof of the capability of wastewater surveillance for COVID-19 in India through detection of genetic material of SARS-CoV-2. Sci Total Environ 746:141326. https://doi.org/ 10.1016/j.scitotenv.2020.141326

La Rosa G, Fratini M, della Libera, S., Iaconelli, M., \& Muscillo, M. (2012) Emerging and potentially emerging viruses in water environments. Annali Dell'istituto Superiore Di Sanita 48(4):397-406. https://doi.org/10.4415/ANN_12_04_07

La Rosa G, Iaconelli M, Mancini P, Bonanno Ferraro G, Veneri C, Bonadonna L, Lucentini L, Suffredini E (2020) First detection of SARS-CoV-2 in untreated wastewaters in Italy. Sci Total Environ 736:139652. https://doi.org/10.1016/j.scitotenv.2020. 139652

Leung N, Chu D, Shiu E, Chan KH, McDevitt JJ, Hau B, Yen HL, Li Y, Ip D, Peiris J, Seto WH, Leung GM, Milton DK, Cowling BJ (2020) Respiratory virus shedding in exhaled breath and efficacy of face masks. Nat Med 26(5):676-680. https://doi.org/ 10.1038/s41591-020-0843-2

Liu L, Yang D, Liu G (2019) Signal amplification strategies for paper-based analytical devices. Biosens Bioelectron 136:60-75. https://doi.org/10.1016/j.bios.2019.04.043

Liu WY, Chuang YC, Liu TJ, Chien CW, Tung TH (2021) Insights from the comparisons of SARS-CoV and COVID-19 outbreaks: the evidence-based experience of epidemic prevention in China. Medicine 100(6):e24650. https://doi.org/10.1097/MD.00000 00000024650

Lu, R., Zhao, X., Li, J., Niu, P., Yang, B., Wu, H., Wang, W., Song, H., Huang, B., Zhu, N., Bi, Y., Ma, X., Zhan, F., Wang, L., Hu, T., Zhou, H., Hu, Z., Zhou, W., Zhao, L., Chen, J., ... Tan, W. (2020). Genomic characterisation and epidemiology of 2019 novel coronavirus: implications for virus origins and receptor binding. Lancet (London, England), 395(10224), 565-574. https://doi.org/10.1016/S0140-6736(20)30251-8

Mao K, Zhang H, Yang Z (2020) Can a paper-based device trace COVID-19 sources with wastewater-based epidemiology? Environ Sci Technol 54(7):3733-3735. https://doi.org/10.1021/acs. est.0c01174

Medema G, Heijnen L, Elsinga G, Italiaander R, Brouwer A (2020) Presence of SARS-Coronavirus-2 RNA in sewage and correlation with reported COVID-19 prevalence in the early stage of the epidemic in the Netherlands. Environ Sci Technol Lett 7(7):511-516. https://doi.org/10.1021/acs.estlett.0c00357

Nasseri, S., Yavarian, J., Baghani, A. N., Azad, T. M., Nejati, A., Nabizadeh, R., Hadi, M., Jandaghi, N., Vakili, B., Vaghefi, S., Baghban, M., Yousefi, S., Nazmara, S., \& Alimohammadi, M. (2021). The presence of SARS-CoV-2 in raw and treated wastewater in 3 cities of Iran: Tehran, Qom and Anzali during coronavirus disease 2019 (COVID-19) outbreak. Journal of environmental health science \& engineering, 19, 573-584. Advance online publication. https://doi.org/10.1007/s40201-021-00629-6

Nowicki P, Klos J, Kokot ZJ (2014) Amphetamines in wastewater of the city Poznań (Poland)-estimation of drug abuse. Acta Pol Pharm 71(1):25-33

Parsa SM (2021) Reliability of thermal desalination (solar stills) for water/wastewater treatment in light of COVID-19 (novel coronavirus "SARS-CoV-2") pandemic: what should consider? Desalination 512:115106. https://doi.org/10.1016/j.desal.2021. 115106

Randazzo W, Truchado P, Cuevas-Ferrando E, Simón P, Allende A, Sánchez G (2020) SARS-CoV-2 RNA in wastewater anticipated COVID-19 occurrence in a low prevalence area. Water Res 181:115942. https://doi.org/10.1016/j.watres.2020.115942

Rimoldi SG, Stefani F, Gigantiello A, Polesello S, Comandatore F, Mileto D, Maresca M, Longobardi C, Mancon A, Romeri F, Pagani C, Cappelli F, Roscioli C, Moja L, Gismondo MR, Salerno
F (2020) Presence and infectivity of SARS-CoV-2 virus in wastewaters and rivers. Sci Total Environ 744:140911. https://doi.org/ 10.1016/j.scitotenv.2020.140911

Saif LJ (1999) Comparative pathogenesis of enteric viral infections of swine. Adv Exp Med Biol 473:47-59. https://doi.org/10.1007/ 978-1-4615-4143-1_4

Sbaoui Y, Bennis F, Chegdani F (2021) SARS-CoV-2 as enteric virus in wastewater: which risk on the environment and human behavior? Microbiology Insights 14:1178636121999673. https://doi. org/10.1177/1178636121999673

Senta I, Krizman I, Ahel M, Terzic S (2014) Assessment of stability of drug biomarkers in municipal wastewater as a factor influencing the estimation of drug consumption using sewage epidemiology. Sci Total Environ 487:659-665. https://doi.org/10.1016/j.scito tenv.2013.12.054

Tanhaei M, Mohebbi SR, Hosseini SM, Rafieepoor M, Kazemian S, Ghaemi A, Shamloei S, Mirjalali H, AsadzadehAghdaei H, Zali MR (2021) The first detection of SARS-CoV-2 RNA in the wastewater of Tehran, Iran. Environ Sci Pollut Res 28:38629-38636. https://doi.org/10.1007/s11356-021-13393-9

Upfold NS, Luke GA, Knox C (2021) Occurrence of human enteric viruses in water sources and shellfish: a focus on Africa. Food Environ Virol 13(1):1-31. https://doi.org/10.1007/ s12560-020-09456-8

Wang J, Feng H, Zhang S, Ni Z, Ni L, Chen Y, Zhuo L, Zhong Z, Qu T (2020) SARS-CoV-2 RNA detection of hospital isolation wards hygiene monitoring during the coronavirus disease 2019 outbreak in a Chinese hospital. International Journal of Infectious Diseases: IJID: Official Publication of the International Society for Infectious Diseases 94:103-106. https://doi.org/10.1016/j.ijid. 2020.04.024

Wang XW, Li JS, Jin M, Zhen B, Kong QX, Song N, Xiao WJ, Yin J, Wei W, Wang GJ, Si BY, Guo BZ, Liu C, Ou GR, Wang MN, Fang TY, Chao FH, Li JW (2005) Study on the resistance of severe acute respiratory syndrome-associated coronavirus. J Virol Methods 126(1-2):171-177. https://doi.org/10.1016/j.jviromet.2005. 02.005

WHO (2015) Summary of probable SARS cases with onset of illness from 1 November 2002 to 31 July 2003 (based on data as of the 31 December 2003). https://www.who.int/publications/m/item/ summary-of-probable-sars-cases-with-onset-of-illness-from-1november-2002-to-31-july-2003. Accessed June 252021

WHO (2020) 2019 Novel Coronavirus (2019-nCoV): Strategic preparedness and response plan. https://www.who.int/publications/i/ item/strategic-preparedness-and-response-plan-for-the-new-coron avirus. Accessed June 252021

Wu, F., Zhang, J., Xiao, A., Gu, X., Lee, W. L., Armas, F., Kauffman, K., Hanage, W., Matus, M., Ghaeli, N., Endo, N., Duvallet, C., Poyet, M., Moniz, K., Washburne, A. D., Erickson, T. B., Chai, P. R., Thompson, J., \& Alm, E. J. (2020). SARS-CoV-2 titers in wastewater are higher than expected from clinically confirmed cases. mSystems, 5(4), e00614-20. https://doi.org/10.1128/mSyst ems.00614-20

Wurtzer, S., Marechal, V., Mouchel, J. M., Maday, Y., Teyssou, R., Richard, E., Almayrac, J. L., \& Moulin, L. (2020). Evaluation of lockdown effect on SARS-CoV-2 dynamics through viral genome quantification in waste water, Greater Paris, France, 5 March to 23 April 2020. Euro surveillance : bulletin Europeen sur les maladies transmissibles $=$ European communicable disease bulletin, 25(50), 2000776. https://doi.org/10.2807/1560-7917.ES. 2020.25.50.2000776

Xiao F, Sun J, Xu Y, Li F, Huang X, Li H, Zhao J, Huang J, Zhao J (2020a) Infectious SARS-CoV-2 in feces of patient with severe COVID-19. Emerg Infect Dis 26(8):1920-1922. https://doi.org/ 10.3201/eid2608.200681 
Xiao F, Tang M, Zheng X, Liu Y, Li X, Shan H (2020b) Evidence for gastrointestinal infection of SARS-CoV-2. Gastroenterology 158(6):1831-1833.e3. https://doi.org/10.1053/j.gastro.2020.02. 055

Yang Z, Kasprzyk-Hordern B, Frost CG, Estrela P, Thomas KV (2015) Community sewage sensors for monitoring public health. Environ Sci Technol 49:5845-5846. https://doi.org/10.1021/acs.est. $5 \mathrm{~b} 01434$

Yetisen AK, Akram MS, Lowe CR (2013) Paper-based microfluidic point-of-care diagnostic devices. Lab Chip 13(12):2210-2251. https://doi.org/10.1039/c3lc50169h

Yousefi M, Oskoei V, Jonidi Jafari A, Farzadkia M, Hasham Firooz M, Abdollahinejad B, Torkashvand J (2021) Municipal solid waste management during COVID-19 pandemic: effects and repercussions. Environ Sci Pollut Res Int 28:32200-32209. https://doi.org/ 10.1007/s11356-021-14214-9

Zaneti RN, Girardi V, Spilki FR, Mena K, Westphalen A, da Costa Colares ER, Pozzebon AG, Etchepare RG (2021) Quantitative microbial risk assessment of SARS-CoV-2 for workers in wastewater treatment plants. Sci Total Environ 754:142163. https://doi.org/10.1016/j.scitotenv.2020.142163

Zhao Z, Cui H, Song W, Ru X, Zhou W, Yu X (2020) A simple magnetic nanoparticles-based viral RNA extraction method for efficient detection of SARS-CoV-2. BioRxiv. https://doi.org/10.1101/ 2020.02.22.961268

Zuccato E, Chiabrando C, Castiglioni S, Calamari D, Bagnati R, Schiarea S, Fanelli R (2005) Cocaine in surface waters: a new evidence-based tool to monitor community drug abuse. Environmental Health: a Global Access Science Source 4:14. https://doi. org/10.1186/1476-069X-4-14

Publisher's note Springer Nature remains neutral with regard to jurisdictional claims in published maps and institutional affiliations. 